Dicle University Journal of Engineering (DUJE)

web: http://dergipark.gov.tr/dumf

Derleme Makalesi / Review Article

\title{
Yüksek Hızlı Demiryolları, Yolcu Ve Yük Taşımacılığı Karşılaştırmaları Bağlamında Küresel Ölçekli Bir Derleme Çalışması
}

\section{A Review on the Context of Comparison of Passenger and Freight Transport and Highspeed Railways}

\author{
Mehmet Fatih Altan ${ }^{1 *}$, Mehmet Çağrı Kızıltaş² \\ ${ }^{1}$ Ístanbul Aydın Üniversitesi, İşsaat Mühendisliği Bölümü, İstanbul, mehmetaltan@aydin.edu.tr \\ ${ }^{2}$ Ístanbul Ticaret Üniversitesi, Inşaat Mühendisliği Bölümü, İstanbul, mckiziltas@ ticaret.edu.tr
}

\begin{tabular}{|c|c|}
\hline MAKALE BİLGİLERİ & ÖZET \\
\hline Makale geçmişi: & $\begin{array}{l}\text { Yüksek hızlı demiryollarının bir tanımı yapılacak olursa bu sistemlerin altyapılarının } 200 \mathrm{~km} / \mathrm{saat} \text { 'in üzerinde } \\
\text { hızlara imkân verdiği belirtilebilir. Ancak bugünlerde yüksek hızlı demiryollarının } 300 \mathrm{~km} / \mathrm{saat} \text { 'lerin üzerindeki }\end{array}$ \\
\hline Geliş: 12 Mart 2018 & hızları yakaladığı da bir vakadır. Bu değer test sürüşlerinde 500 km/saat'lik hızları dahi bulmaktadır. Günümüzde \\
\hline Düzeltme: 12 Temmuz 2018 & küresel ölçekte hızlı kara ulaştırma sistemleri ikiye ayrılmaktadır. Bunlardan birisi çelik tekerlek ve çelik ray olarak \\
\hline Kabul: 24 Temmuz 2018 & açıklanabilecek olan demiryollarıdır. Uluslararası demiryolları birliğine (UIC) göre yüksek hız, bir dizi işletim \\
\hline Anahtar kelimeler: & $\begin{array}{l}\text { koşulu ve altyapı dâhilinde değerlendirilebilecek bir husustur. UIC bu kapsamda yüksek hızın alt limitini } 250 \\
\mathrm{~km} / \text { saat olarak tayin etmiş olup bu değer yüksek hız standartlı altyapı ve işletim koşulları dâhilindedir. Bu çalışma }\end{array}$ \\
\hline $\begin{array}{l}\text { Yüksek hızlı demiryolları, } \\
\text { Yolcu taşımacıllığı, Yük } \\
\text { taşımacılığı, Altyapı, Türel } \\
\text { dağılım, İşletme hızı }\end{array}$ & $\begin{array}{l}\text { kapsamında öncelikle yüksek hızlı demiryollarının altyapı, hız, araç vs. kıstaslara göre tanımı ortaya konmuştur. } \\
\text { Ardından avantajları ve potansiyel etkileri incelenmiştir. Sosyal etkilerin kapsamı ele alınmıştır. Bu bağlamda da } \\
\text { talep ve kapasite unsurları değerlendirilmiştir. AB ve ABD merkezli değerlendirmelerin ardından sonuçlar } \\
\text { paylaşılmıştır. Giriş bölümünde yüksek hızlı demiryolları tanıtılmış, ardından çeşitli unsurlara göre yüksek hızlı } \\
\text { demiryolları sınıflandırması ile ilgili konular ortaya konmuş, takibinde bu ulaştırma türünü etkili ve ayırt edici } \\
\text { kılan unsurlar açıklanmıștır. Son olarak da bu bağlamda sonuçlar paylaşılmıștır. }\end{array}$ \\
\hline
\end{tabular}

Doi: $10.24012 /$ dumf. 404832

\begin{tabular}{|c|c|}
\hline ARTICLE INFO & ABSTRACT \\
\hline Article history: & $\begin{array}{l}\text { It can be mentioned that the transportation mode gives possibility to minimum } 200 \mathrm{~km} / \mathrm{h} \text { speeds if a definition will } \\
\text { be done for high speed railways. But it is a case that high speed railways have caught } 300 \mathrm{~km} / \mathrm{h} \text { operation speeds }\end{array}$ \\
\hline Received: 12 March 2018 & nowadays. This value reachs $500 \mathrm{~km} / \mathrm{h}$ speeds even on test drives. \\
\hline Revised: 12 July 2018 & \\
\hline Accepted: 24 July 2018 & \multirow{3}{*}{$\begin{array}{l}\text { Today speed inland transportation systems split in half on global scale. One of them is railways that can be } \\
\text { expressed as steel tyred and steel railed systems. High speed according to International Union of Railways (UIC) } \\
\text { is an issue that can be evaluated within a set of operational conditions and limits and infrastructure. On this context } \\
\text { International Union of Railways (UIC) has specified the lower limit of high speed as } 250 \mathrm{~km} / \mathrm{h} \text { that is on the } \\
\text { parallel of high speed railway infrastructural and operational conditions. Within this framework, firstly the } \\
\text { definition of high speed railways in terms of speed, infrastructure, vehicular etc. conditions is revealed. Then the } \\
\text { advantages and potential impacts of high speed railways are reviewed. And the context of the social effects of high } \\
\text { speed railways (HSR) is evaluated. In this regard demand and capacity elements are discussed. Results are shared } \\
\text { after the considerations which are United States Of America (USA) and European Union (EU) focused. }\end{array}$} \\
\hline Keywords: & \\
\hline $\begin{array}{l}\text { Infrastructure, passenger } \\
\text { transport, high speed railways }\end{array}$ & \\
\hline
\end{tabular}

* Sorumlu yazar / Correspondence

Mehmet Fatih ALTAN

$\triangle$ mehmetaltan@ticaret.edu.tr 


\section{Giriş}

Yüksek hızlı demiryolları, demiryolu ulaştırma türünün gelişmiş bir çeşididir. Hızı, az yer kaplaması, taşıma kapasitesi, çevre dostu olması, petrol kullanımını gerektirmemesi gibi avantajlı özellikleri bulunmaktadır. Yüksek hızlı demiryollarının (YHD) tanımı ile ilgili çeşitli görüssler ortaya konmaktadır. İlk olarak Japonya Shinkansen Kurumu tarafindan 1970 yılında YHD için $200 \mathrm{~km} / \mathrm{saat}$ hızı yeterli görülmüş iken zaman içerisinde altyapı, hacim ve kapasiteye bağlı olarak Avrupa ve Japonya'da 250 km/saat ve üzeri hızlara ulaşılmıştır. Günümüzde trenler ilk örneklerinin 10 katının üzerinde hızlara ulaşmış durumdadır. Fakat bu hızlar belli koşullar dâhilinde yakalanmaktadır.

Bir yüksek hızlı demiryolu hattı elde etmede yüksek hız altyapısına dayalı sistematik bir oluşum söz konusu olmaktadır [1]. Ortaya çıkarılacak hatlar dizisinin sistemin başarısı ve bütünlüğü ile doğrudan ilişkili olduğu unutulmamalıdır. Yüksek hızları yakalamada yüksek hılı trenlerin işletilebileceği özel koşullara sahip altyapılar birer gereksinimdir. Bütün bunlardan dolayı yüksek hızlı demiryollarının tek bir tanımı ya da standardına henüz ulaşılamamıştır. Söz konusu karmaşık yapıdan ötürü yüksek hızlı demiryollarının tek bir standardı söz konusu değildir. Ancak çeşitli şartlar altında ortak değerlendirme imkânları sunan birkaç tanımdan söz etmek mümkündür. Bir hattın YHD sinıfinda telakki edilmesi ile ilgili altyap1, hiz, hizmet parametreleri gibi değerlendirme kıstasları bulunmaktadır. YHD hatlarında nüfus yoğun bölgelerde gürültü kaynaklı sıkıntılar nedeni ile hızın $110 \mathrm{~km} / \mathrm{saat}$ ve uzun köprü ve tünellerin olduğu yerlerde de güvenlik ve taşıma kapasitesi sebepleri ile hızın 160-180 km/saat ile sinırlandırıldığ bilinmektedir [2]. Yani buradan hareketle, söz konusu ulaştırma türünün en önemli ve en ayırt edici özelliklerinden birisi olarak hız unsurunun da ilgili işletim koşulları ya da gereksinimlere göre çeşitlenebildiği açıkça anlaşılmaktadır.

\section{Materyal ve Yöntem}

Yüksek hızlı trenlerin tanımına altyapı yönü ile bakıldığında birçok kavramın ihtiva edildiği görülmektedir. Bu bağlamda altyapı inşası büyük ölçüde ya da tamamen $250 \mathrm{~km} /$ saat ve üzeri hızlar nazarı ile gerçekleştirildi ise bu noktada yüksek hızlı demiryolu hattı tanımlaması yapılır. Altyapı açısından yüksek hızlı demiryolunun tanımı birçok kavramı kapsamaktadır.

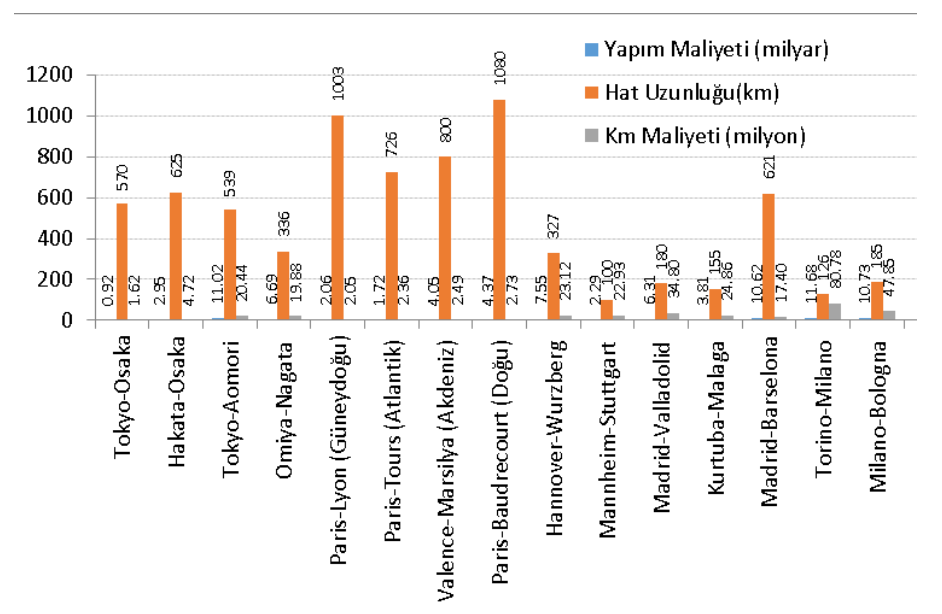

Şekil 1. Gidiş-Geliş Bilet Fiyatı, Hat Uzunluğu ve Seyahat Süresi Karşılaştırması (YHDHavayolu) [3]

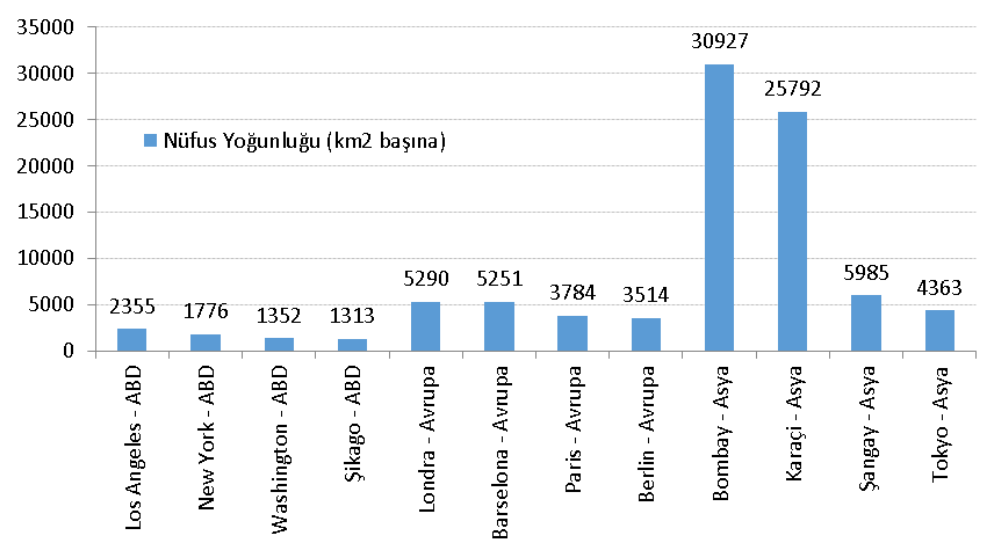

\section{Şekil 2. Dünya Şehirlerinde Nüfus Yoğunluğu} [4]

Büyük yükselti ve dar boğaz geçişleri ve farklı gabarili ray kullanımları ile çeşitli kendine has sebeplere bağlı olarak belirli hız sınırlamaları olsa da $200 \mathrm{~km} / \mathrm{saat}$ 'lik hızlarda işletime el veren konvansiyonel hatlar da YHD sinıfinda kabul 
edilebilmektedir (AB Ulaştırma Politikaları-1). Şekil 1'de çeşitli ulaştırma koridorlarında yüksek hızlı demiryolları ve havayolu ulaştırma türü karşılaştırması verilmiştir [4].

\section{Çeken ve Çekilen Araçlar Açısından Yüksek Hızlı Demiryolları}

Sabit düzenli motor ve vagon gruplarından meydana gelen ve ticari işletimlerde $250 \mathrm{~km} /$ saat ve üzeri hızları yakalayabilen dizilere yüksek hızlı tren (YHT) denmektedir. Bundan da öte çeşitli kısıtlar altında $200 \mathrm{~km} /$ saat değerlerine tekabül eden yatar gövdeli trenlerle benzeşen fakat daha yüksek düzeylerde hizmet kalitesine sahip olan yüksek hızlı trenler (YHT) oldukları da söylenebilir.

\section{İşletim Sistemleri Açısından Yüksek Hızlı Demiryolları}

Demiryolu işletmeciliğine göre değişen bu tanım için ayrı durum söz konusudur.

- $\mathrm{Bu}$ noktadaki ilk sistem türü, konvansiyonel trenlerin konvansiyonel hatlarda, yüksek hızlı trenlerin de yüksek hılı hatlarda işletilmesi durumudur. Buna örnek Japonya'dan JR Central ve JR East olarak verilebilir.

- İkinci türde, konvansiyonel hatlarda ilgili kısıt ve şartlarda hem yüksek hızlı ve hem de konvansiyonel trenlerin çalışması söz konusudur. Ancak yüksek hızlı hatlarda sadece yüksek hızlı trenler çalışmaktadır. Buna örnek olarak Fransız SNCF verilebilir.

- Üçüncü türde ise tam tersine, yüksek hızlı hatlarda ilgili kısıtlar dâhilinde hem yüksek hızlı ve hem de konvansiyonel trenler işletilir iken konvansiyonel hatlarda ise sadece konvansiyonel trenler çalışmaktadır. Bunun örneği ise İspanyol RENFE işletimidir.

- Dördüncü tür ise yüksek hızlı hatlarin da konvansiyonel hatlarında aynı anda ve birlikte, hem konvansiyonel trenlerin ve hem de yüksek hızlı trenlerin işletimine açık olduğu durumdur. Buna örnek ise İtalya'da Trenitalia ve Almanya'da Deutsche Bank'tır [5].

Şekil 3'te dünyada önemli yüksek hızlı demiryolu hatlarının maliyetleri verilmektedir [6].

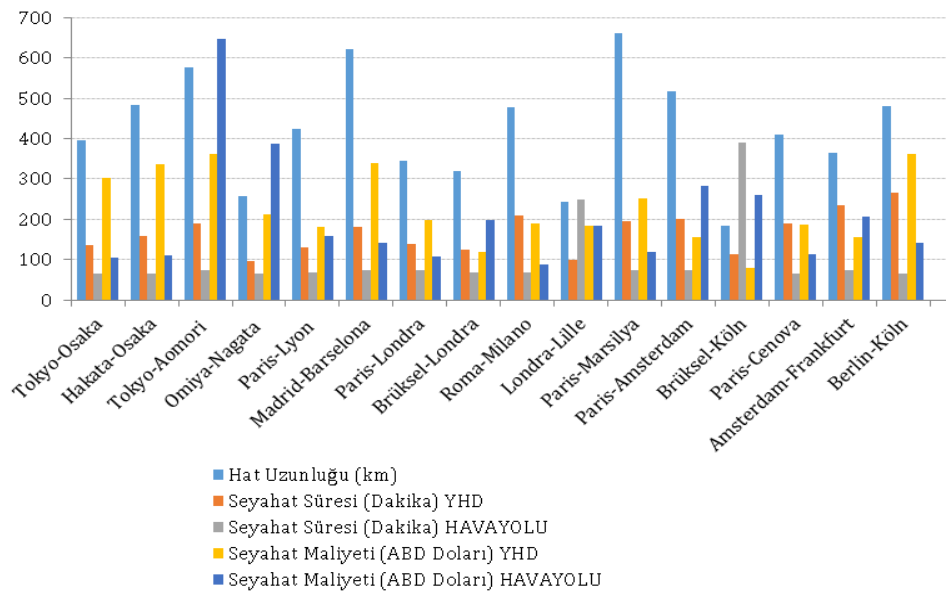

\section{Şekil 3. Önde Gelen YHD Hatlarında Yapım Maliyetleri (ABD Dolarl) [6]}

\section{Yüksek Hızlı Demiryolunun Avantajları}

Günümüze değin yüksek hızlı demiryollarının kazandığı yaygınlık ve ulaştığ memnuniyette etkili birçok faktör söz konusudur. Yüksek hızlı demiryolları hız ve kapasite parametrelerini üst düzeyde sunduğundan dolayı nüfus yoğun olan bölgelerde talep görmektedir. $\mathrm{Bu}$ özelliklerin en iyi temsillerinden birisi Japonya'dır. Tokyo'dan 10 tren/saat siklikla hareket eden yüksek hızlı trenler 2300 yolcu/trenXsaat kapasite ile hizmet vermektedir. 200 ila $600 \mathrm{~km}$ arası mesafelerde yüksek hızlı demiryolları, yaygınlık kazanmış olduğu Avrupa ve Asya kıtaları için, havayollarına nazaran daha rekabetçi görünmektedir. Yüksek hızlı demiryollarının çevresel kirlilik bazında önemli avantajlarından birisi kişi başına yolculuğa düşen 
enerji tüketiminin düşüklüğüdür. Yüksek hızlı demiryolları için söz konusu değer havayolu ulaştırma türü için olanın 3'te 1'i iken özel otomobil ulaştırma türü için olanın yaklaşık yarısı kadardır. Yüksek hızlı demiryolu ulaştırma türünün önde olduğu bir başka hizmet parametresi ise güvenliktir. Yüksek hızlı demiryollarında kazalar ve kaza kayıpları minimal seviyelerdedir. Yüksek hızlı demiryolları çeşitli ilave altyapı işleri gerektirmektedir [6]. Söz konusu ulaştırma türünün avantajları dezavantajlarına nazaran oldukça fazladır. Tünel ve viyadük inşalarının yüksek eğimli arazilerde artış göstermesi işletme ve yatırım maliyetlerinde artışlara neden olmaktadır. Her halükarda demiryollarının toplam maliyetleri, karayolu maliyetlerinin altında olup bunun nedenlerinden birisi de az yer kaplamasıdır. Yüksek hızlı demiryollarında hız artışına paralel gürültü ve titreşimde kaydedilen artış ise bir başka dezavantaj olarak göze çarpmaktadır. $\mathrm{Bu}$ noktadaki handikabın azaltılması ya da ortadan kaldırılması ile ilgili güncel çalışmalar yürütülmeye devam etmektedir.

Kent periferilerinin uzak mesafelere yayılmasının nedenlerinden birisi de yüksek hızlı demiryolu ulaştırma türünün kaydettiği hız değerleridir. Yüksek hızlı demiryollarının hıza dayalı olarak seyahat süresinde kaydettiği önemli düşüşler sayesinde 400 km'nin üzerindeki mesafeye sahip kentler arasında günlük ev-iş yolculukları imkânı doğmuş olup bu durum da söz konusu kentlerin ekonomik hareketliliklerine yansımaya başlamıştır. Havayollarının yönetim ve ilerletilmesi yüksek hızlı demiryollarına nazaran daha maliyetli olmaktadır. Havaalanlarında da uçakların işletim, bakım ve park gibi aşamalarından kaynaklı maliyetleri de buna ilave olarak düşünülmelidir. Aynı zamanda uçakların yakıt tüketimi de trenlere kıyasla çok yüksektir. Buradan hareketle işletme maliyetleri yönünden bakıldığında da yüksek hızlı demiryollarındaki maliyetler havayollarındakinin 3'te 1'ini teşkil etmekte olup bu noktada söz konusu ulaştırma türü için bir tercih sebebi olarak ortaya çıkmaktadır. Yüksek hızlı demiryollarının rekabetçiliğgi, diğer ulaştırma türlerinde hizmet parametrelerini yükseltmenin bir itici gücü olma fonksiyonunu da üstlenmektedir. Söz konusu ulaştırma türü konfor, güvenlik, hız, seyahat süresi, toplam seyahat süresi ve frekans gibi hizmet parametrelerini üst düzeyde sunmaktadır. Yüksek hızlı trenlerin sağladığı yolculuk kapasitesi 400.000'lere kadar çıkabilmektedir. $\mathrm{Bu}$ rakamlar genel trafik tıkanıklığının iyileştirilmesinde de olumlu bir etkiye sahip olmaktadır. Birim enerji tüketimi bazlı bakıldığında ise yüksek hızlı demiryolları uçakların 9'da 1'i kadar bir değere sahip olmaktadır. YHD işletimlerinde kaza kayıpları düşük olup $200 \mathrm{~km} / \mathrm{saat}$ 'in üzerinde kaza gerçekleşmemiş durumdadır [7]. Mevcut durumda küresel ölçekte, yüksek hızlı demiryolu işletimlerine bakıldığında söz konusu işletim hızları halen $350 \mathrm{~km} / \mathrm{saat}$ 'lerin altında kalmaktadır. Ancak test hizlarında Fransa, Japonya ve Almanya'da $350 \mathrm{~km} /$ saat'lerin üzerine çıkılmaktadır. $\mathrm{Bu}$ noktadaki dünya rekoru 2008 yılı itibari ile kaydedilen hızla Fransız TGV'de olup söz konusu trenler ParisStrazburg arası test sürüşlerinde $575 \mathrm{~km} / \mathrm{saat}$ değerleri kaydetmiştir. Maglev trenleri ile ise bunun ötesindeki hızlara 2003 yılı itibari ile Japonya'da, sonrasında da Çin'de ulaşılmıştır. Aşağıda yüksek hızlı demiryolları ile ilgili çeşitli kritik noktalar belirtilmektedir:

- Hemzemin geçitler demiryollarında en çok kaza olan bölgelerden birisini teşkil etmektedir. Buradaki kazalara genellikle işaret levhalarına riayet etmeyen karayolu araçları neden olmaktadır. Hemzemin geçitler $140 \mathrm{~km} / \mathrm{saat}$ 'in üzerindeki işletim hızlarının kaydedildiği yerlerde bulunmamaktadir.

- Söz konusu ulaştırma türünde insan ve hayvan geçişlerinin engellenmesi için ihata duvarı uygulamaları yer almaktadır. 
- Söz konusu ulaştırma türü altyapı yapımı standartları anlamında konvansiyonel hatların oldukça ilerisindedir. Demiryolu platformu ve ilgili unsurları ileri teknik imkânlar dâhilinde uluslararası standartlara uygun şekil ve malzemeler ile yapılmaktadır.

- Ters yönlerden gelen iki yüksek hızlı tren arasındaki hız farkı yerine göre $600 \mathrm{~km} /$ saat'leri bulmaktadır. Dolayısı ile hatlar arasındaki mesafe önemli bir noktadır. Yüksek hızlarda karşılıklı geçişlerde trenler yüksek bir hava basıncı meydana getirmektedir. $\mathrm{Bu}$ da ani basınç değişimlerine birbirlerini maruz biraktıkları anlamına gelmektedir. Dolayısı ile yüksek hızlı tren hatları arasindaki mesafeler konvansiyonel hatla nazaran daha büyüktür.

- Yüksek hizların elde edilebilmesinin bir gereği olarak yüksek hızlı demiryollarındaki kurblar da daha büyük olmaktadır.

- Yüksek hizlı trenlerin birbirleri üzerine basınç etkisinden hareketle yüksek hızlı demiryolu tünelleri de farklı tasarım ilkelerine göre yapılandirılır.

Zaman tasarrufları yüksek hızlı trenlerde en kolay genelleştirme unsurlarından birisidir. Ancak bu unsurun hassasiyet derecesini ortadaki amaç belirlemektedir: kapasite artırımı, seyahat süresinin kentler arası bazda azatlımı ya da karşılaştırma yapılan taşımacılık türleri. $\mathrm{Bu}$ noktada Tokyo-Osaka seyahatleri örnek verilebilir. $\mathrm{Bu}$ hattaki seyahat süresi Tokaido Shinkansen öncesi 7 saat iken ardından bu süre 4 saate inmiş olup son tahlilde ise yaklaşı 2,5 saattir. Tablo 1'de karşılaştırmalı olarak demiryolu ile havayolu türel payları verilmişt $\mathrm{r}$ [8].

Tablo 1. Ulaştırma Koridorlarında Demiryolu Havayolu Türel Dağılımı ve Seyahat Süreleri [8]

\begin{tabular}{c|ccc}
\hline Koridor & Yıl & $\begin{array}{c}\text { Seyahat } \\
\text { Süresi (dk) }\end{array}$ & $\begin{array}{c}\text { Türel } \\
\text { Pay (\%) }\end{array}$ \\
\hline
\end{tabular}

\begin{tabular}{c|lcc}
\hline Paris-Brüksel & 2006 & 85 & 100 \\
\hline Paris-Lyon & 1985 & 135 & 91 \\
\hline Madrid-Sevilya & 2003 & 140 & 83 \\
\hline Brüksel-Londra & 2005 & 140 & 60 \\
\hline Tokyo-Osaka & 2005 & 150 & 81 \\
\hline Madrid-Barselona & 2009 & 158 & 47 \\
\hline Paris-Londra & 2005 & 160 & 66 \\
\hline Tokyo-Okayama & 2005 & 196 & 57 \\
\hline Paris-Cenova & 2003 & 210 & 35 \\
\hline Tokyo-Hiroşima & 2005 & 231 & 47 \\
\hline Paris-Amsterdam & 2004 & 250 & 45 \\
\hline Paris-Marsilya & 2000 & 260 & 45 \\
\hline Londra-Edinburg & 1999 & 265 & 29 \\
\hline Londra-Edinburg & 2004 & 270 & 18 \\
\hline Tokyo-Fukuoka & 2005 & 299 & 9 \\
\hline usek h11 tren & hizmeti & & \\
\hline & & & \\
\hline & & & \\
\hline & & & \\
\hline
\end{tabular}

Yüksek hızlı tren hizmeti öncesi Madrid ve Sevilya arası seyahat süresi 6,5 saat iken AVE hizmetleri sonrası bu sürede 4 saatlik bir azalma kaydedilmiştir. Londra-Paris arası seyahat süresi Manş Tüneli ile birlikte $\% 50$ azalmış olup bu yapının inşası sonrası Londra-Brüksel aras1 zaman tasarrufu bunun da fevkindedir. İngiltere'de batı kıyıdaki hatta ve Almanya'da Frankfurt-Köln hattında yüksek hızlı tren hizmeti sonrası kaydedilen seyahat süresi iyileşmeleri ise \%30'lardan \%60'lara, farklı koşullar altında değişen seyahat süresi iyileşmelerine işaret etmektedir. Japonya'da 1990'l1 y1llarda yıllık ortalama zaman kazançları 3.700.000.000 saat/yıl olup bu tasarruflar ilerleyen yıllarda daha da artmaya devam etmiştir.

Tablo 2. Önemli Demiryolu Hiz Rekorlar1 [9]

\begin{tabular}{|c|c|}
\hline Ülke & $\begin{array}{c}\text { Hiz } \\
(\mathbf{k m} / \mathbf{s a a t})\end{array}$ \\
\hline 1964 - JAPONYA - Tokaido Shinkansen & 210 \\
\hline 1981 - FRANSA - TGV, Paris-Lyon & 260 \\
\hline $\begin{array}{c}1988 \text { - FRANSA - Word Speed Record (WSR), } \\
\text { electric }\end{array}$ & 408 \\
\hline
\end{tabular}




\begin{tabular}{|c|cc|}
\hline 1990 - FRANSA - WSR, electric & 515 & A \\
\hline 2003 - JAPONYA - WSR, maglev & 581 & tas \\
\hline 2007 - FRANSA - WSR, electric & 574,8
\end{tabular}

Söz konusu yeni bir yüksek hızlı demiryolu yatırımı ise daha kapsamlı, karmaşık ve gerekli olan değerlendirme ise otomobil ve uçak ile yapılacak olan karşılaştırmalardır. Yapılan bu tarz araştırmalarda farklı ülkelerin de dâhil olması ile $130 \mathrm{~km} / \mathrm{saat}$ 'lerdeki konvansiyonel hızlardan yüksek hızlı tren değerlerine kat edilmesi muhtemel artışlar ile ortalama 45-50 dakikaya varan seyahat süresi kısalmaları ortaya çıkmaktadır. Karayolu ulaştırma türü ile bir karşılaştırma söz konusu olduğunda, zaman tasarruflarında varış noktası mesafesi bazlı yaklaşımlar söz konusu olmaktadır. Bu durumda tıkanıklık değerlerinde normalin altında iyileşmeler yakalanmış olup söz konusu durum daha çok 80 km'nin altındaki mesafeler için gerçekleşmiştir [9]. Tablo 2'de dünyada önemli demiryolu hız rekorları verilmektedir [10].

\section{Talep ve Kapasite}

2000 y1lı verilerine göre A.B.D.'de demiryolunun türel dağılımdaki payı \%38 olup 2.468.206 milyon tonxkm'lik taşıma kapasitesine haizdir, buna karşın aynı dönemde 3.068.000 milyon tonxkm ise AB'deki toplam taşımayı ifade etmektedir. Söz konusu taşıma kapasitesi A.B.D.'nin toplam karasal taşımasının \%58,82'si olup bu oran AB'de \%15,11 olarak gerçekleşmiştir. Hâlihazırda $\mathrm{AB}$ zaten A.B.D.'nin toplam taşımacılı̆̆ının yaklaşık yarısını gerçekleştirebilir iken bunda da baskın olan denizyolu olup \%41,10'luk bir orana haizdir. AB'de diğer taşımacılık türlerinin toplamı ise ancak \%48,24'tür. Bu noktada demiryollarının avantajları tekrar zikredilecek olur ise temiz ve güvenli bir tür olması başta belirtilebilir. Takibinde ise altyapısının elverişliliği, gelişme açıklığ 1 ve trenlerin taşıma kapasitelerinin büyüklüğü anılabilir [10].
A.B.D. ve Avrupa Birliği'nde 1950'lerde yük taşımasının oranları hemen hemen aynı iken 2000'ler itibari ile bu oran AB'de \%8'inmiş olup A.B.D.'de ise 38 'lere yükselmiştir. $\mathrm{Bu}$ đeğişimlerin büyük bir bölümü sırası ile ürün çeşitlenmesi, coğrafi değişimler, taşıma kilometreleri, yapısal ve doğal değişiklikler iken önemli bir bölümü de sınır alanlarında çoklu işletim noktasındaki yetersizlikler, yolcu ulaştırması, hizmet parametreleri ve kalitesi ile demiryolu operasyonları ile ilgili destekleri de içeren kamu politikasındaki farklılaşmalar ile de ilgilidir. Demiryolları açısından bakıldığında da yük taşımacılığı anlamında mesafeler, A.B.D.'de $\mathrm{AB}$ 'dekine nazaran daha istenen konumda olup bunun bir nedeni de AB'nin 3 katı yüz ölçüme sahip olmasıdır. Ayrıca AB'nin kıyı şeridi uzunluğu da A.B.D.'nin kinin 9 katıdır, bu durum da A.B.D.'de yük taşımacılığında demiryollarının daha öne çıkarmaktadır. Bundan da öte A.B.D.'de demiryolu yük taşımacılığının bir başka destekçisi de kamu politikalarının seyridir. Hem AB ve hem de A.B.D.'de gelişmiş düzeyde otoyol ağları mevcut olması ile birlikte $\mathrm{AB}$ uzunca süredir demiryollarına mali destek sunmaktadır. Bunun devamında da AB demiryollarını sadece devlet elinde milli bir yapıda tahkim etmiş iken A.B.D. demiryollarının özelleştirilmesinde son derece başarılı bir örnekli ortaya koymuştur.

Denizyolu ve havayolu gibi karasal dışı ulaştırma türlerindeki rekabetçilik seviyeleri, ürün farklılaşmaları, yük taşıma mesafeleri ve ulaştırma kapasiteleri gibi parametreler A.B.D. ve $A B$ arasındaki demiryolu ulaştırma türel paylarının farkının öncelikli nedenleridir. Amerika Birleşik Devletleri'ndeki ortalama ulaştırma mesafeleri Avrupa Birliği'ndeki ortalama ulaştırma mesafelerinden gözle görülür ölçüde yüksektir. Ortalama ulaştırma mesafeleri Amerika Birleşik Devletleri (A.B.D.) için 386 $\mathrm{km}$ iken Avrupa Birliği (AB) için ise $132 \mathrm{~km}$ olup bu değerler karasal ulaştırma bazlı değerlerdir. Ortalama nakliyecilik maliyetleri daha makul olduğundan dolayı demiryolu ulaştırma türü uzun mesafeli taşımacılıkta 
tırlardan daha rekabetçi konumdadır. Demiryollarının karasal yük ulaştırmasındaki payı 2000 yılında 0-50 km arasında A.B.D.'de $\% 3$ ve $A B$ 'de $\% 2$ iken $500-1000 \mathrm{~km}$ aras1 mesafeler için ise bu değerler A.B.D.' de $\% 38$ ve AB'de \%21 olarak ortaya çıkmaktadır. Buradan A.B.D.'de ulaştırma mesafesi artışına paralel, demiryolu ulaştırmasının türel payının ciddi artış gösterdiği sonucuna varılmaktadır.

Amerika Birleşik Devletleri ve Avrupa Birliği arasında 413 milyar tonXkm'lik fark taşıma hacmi olarak sadece demiryolu taşıma mesafesinde meydana gelmektedir. Dolayısı ile ortaya çıkan söz konusu fark, A.B.D. ve $A B$ arasındaki kıyı şeridi uzunluğu farkından daha da ötesindeki bir duruma işaret etmektedir (Crafts, 2009).

Amerika Birleşik Devletleri ve Avrupa Birliği için fabrika ürünleri ve kömürün dişındaki ürünler benzerlik göstermekte olup ulaştırması yapılan ürününü çeşitliliği de önemli bir konu olmaktadır. Karasal yük taşımacılığında (demiryolu ve karayolu) kömürünü taşımada tonXkm cinsinden payı A.B.D. için \%23 iken AB için ise $\% 1$ 'lerdedir. A.B.D. ve $A B$ 'de fabrikasyon ürünler için ise söz konusu paylar sirasi ile $\% 10,5$ ve $\% 34$ olarak gerçekleşmektedir. Amerika Birleşik Devletleri demiryollarının Avrupa Birliği demiryollarına nazaran bir avantajı da demiryollarının daha düşük kütleli ürünlerin taşınımında daha rekabetçi olmasıdır.

Demiryolları yük ulaştırması açısından A.B.D. ve $A B$ arasında ürün çeşitliliği esasına göre 397 milyar tonXkm'lik fark ortaya çıkmıştır. Ürün çeşitliliği; denizyolları, iç suyolları ve boru hatları için, karasal ulaştırma türleri olan karayolu ve demiryolu yük taşımacılığı yönünden gösterdiği etkiyi göstermemektedir. Denizyolu-İçsuyolu-Boru hatları lehine bir 124 milyar tonXkm'lik değişim AB'nin ürün taşıma dağılımının A.B.D.'ye uygulanması durumunda ortaya çıkması beklenebilir. AB'de söz konusu taşıma performansında, ürün çeşitliliği paralelinde bütün ulaştırma türleri arasında en büyük etkiyi kömür taşımacılığı göstermektedir. Bunların da ötesinde ulaştırma hacmi değişiminin yeniden bir şekillenmeye tabi olmasında, AB'nin demiryolu ulaştırma türü ve rekabetçi-tamamlayıcı türleri ile ilgili strateji ve politik kararları ana unsur olarak görünmektedir. Daha kapsamlı ve yüksek düzeyli bir bakış açısı ile bu politik proseslerin tamamı ele alınabilir. AB'nin yük taşıması başta olmak üzere demiryolu ulaştırması ile ilgili politik insiyatifleri A.B.D.'ninkinden daha etkin sonuç vermeye adaydır. Hâlihazırda 2000 yılından bu yana çoğu $A B$ ülkesi demiryolu ulaştırma türünde birçok teşviki devreye sokmaktadır [11].

A.B.D.'de AB'ye göre otoyol geçi ücreti uygulamaları daha az yaygınlık kazanmıştır ve yakıt fiyatları ise düşüktür. AB'de yakıt fiyatları A.B.D.'dekinin kabaca iki katı mertebelerinde seyretmekte iken geneli itibari ile bu aralıklar zaman ve coğrafyaya göre çeşitlenmektedir. Ülkeler bazında AB'de otoyol geçiş ücretlendirme uygulamaları otoyol ağının \%12'si ila \%30'u arasında değişmekte iken A.B.D. için ise bu değer sadece \%1,3'ler mertebesindedir. Bunun yanı sıra A.B.D.'de demiryolu ulaştırma türünde doğrudan sübvansiyonlar daha yaygın etkindir, AB'de ise bu süreç birçok prosedüre tabi ve daha dolaylı gerçekleşmektedir. A.B.D.'de hükümet dolaylı yollardan gelir vergilerinden (2001 y1lı itibar ile 538 milyon ABD Doları) önemli bir payı demiryolu sübvansesine ayırmaktadır. AB'de demiryolu yolcu taşımacılığı genel anlamda sübvansiyonların çoğunu almakta olup bu miktarın yaklaşık yarısı da (2001 yılında 38,306 milyon Euro'nun 18,364 milyon Euro'luk bölümü) yük ve yolcu ortak kullanımının altyapısına tahsis edilmektedir. AB'de kentlerarası demiryolu yolcu taşımacılığ 1 payları $\% 6,25^{\prime}$ lerde seyreder iken bu değer A.B.D. için ise $\% 0,32$ 'lerde seyretmektedir. AB'nin politikalarının demiryollarında yolcu taşımacılığını yük taşımacılığına nazaran fazla öncelemesi önemli bir dezavantaj olarak okunmaktadır [11]. 
AB'de kısıtlı olan demiryolu güzergâhlarının yolcu taşımacılığı yönünde özelleştirilmesi ve iyileştirilmesi anlamında ciddi çalışmalar mevcut iken benzer durum yük taşımacılığı alanında ise bu anlamda zikredilememektedir. Çok disiplinli ve birlikte işletim alternatiflerinin teknik imkânları ve sürücülerin uluslar arası demiryolları için birlikte eğitimi ve benzeri insiyatifler ile $\mathrm{AB}$ sathında demiryolu ulaştırma türü yük taşımasının ilerletilmesi söz konusu olabilecektir. Bu noktada finansman kaynakları ve koordinasyonun önemi açıkça otaya çıkmaktadır. $\mathrm{Bu}$ anlamda yolcu ulaştırması ve yük ulaştırması arasında bir dengenin temini de önemlidir, Avrupa Birliği'nde ise bu bağlamda birçok bağlantı noktasında bir dizi sinırlandırmalar söz konusu olmaktadır. Demiryolu ulaştırma türünün türel payının artışında çeşitli doğrudan unsurları; altyapı kalitesinin ilerletilmesi, sinyalizasyon sistemlerinin yeterli temini ve hat kapasitesinin arttırılması olarak zikredilebilir. Bunun da ötesinde ise sistemdeki rekabetin yükseltilmesinin temini ve demiryolu yük ulaştırmasının desteklenmesi anılabilecek hususlardandir.

\section{Türkiye’de Yüksek Hızlı Demiryolları}

Türkiye'de yüksek hızlı demiryollarına giriş geç sayılabilecek bir tarihte başlamıştır. Ancak Fransa, Japonya ve Almanya'daki durumun aksine geç tarihlerde bu ulaştırma türüne yatırıma başlayan İspanya ve Çin gibi iki ülkenin hâlihazırda küresel ölçekte lider ülkeler arasında olduğu da gözden kaçırılmamalıdır. Zira günümüzde Çin, Fransa, İspanya ve Japonya, YHD sektörünün liderleri konumundadır. Ülkemizdeki hızı kurulum süreci dikkate alındığında ise en azından hat uzunluğu bazında Çin ve İspanya'dan sonra 3.büyük olmak gerçek dışı bir hedef olmayacaktır. Çünkü gerçekleştirilmesi planlanan yatırımlar hayata geçtiğinde ortaya çıkacak olan tablo bunu göstermektedir.
Ülkemizde açılan ilk yüksek hız hattı olan Ankara-Eskişehir YHD hattı, Eskişehir-İstanbul etabının da tamamlanması ile birlikte Ankara'dan İstanbul'a kesintisiz yüksek hız erişimini temin etmiştir. Söz konusu ikinci etap tamamlanmadan önce ise bir diğer yüksek hız hatt1 olarak ise Ankara-Konya YHD hatt1 açılmıştır. $\mathrm{Bu}$ hattın takibinde ise KonyaEskişehir YHD bağlantısı tamamlanmıştır. Hâlihazırda İstanbul'dan Konya'ya kadar kesintisiz YHD ulaşımı sağlanmakta olup yakalanan işletim hızları ise 200 ila 250 $\mathrm{km} / \mathrm{saat}$ 'ler bandındadır. İnşası devam eden bir başka hat ise İstanbul-Edirne YHD hattı iken bir diğeri ise Ankara-Afyon-Manisa-İzmir YHD hattıdır. İzmir'e ulaşacak olan hattın inșasında Ankara'dan başlandığında Afyon dolaylarında olduğu görülmektedir. Bir diğer önemli hat ise Ankara-Yozgat-Sivas YHD hattıdır. Bu hattın ise yarısından çoğu tamamlanmış olup inşa süreci devam etmektedir. Sivas-Erzincan-ErzurumKars etabının ise hızlı demiryolu hattı olması öngörülmekte olup buradaki hedef işletim hızları ise $200 \mathrm{~km} /$ saat'lerdir. Görüldüğü üzere esas itibari ile Ankara merkezli olarak dört ana koldan toplama ve dağıtma hedeflenmekte olup ikinci bir Ankara-İstanbul YHD bağlantısı da düşünülmektedir. Eskişehir'e uğramayacak olan hat Bolu dolaylarından geçecek olup mesafe kısaldığı gibi, daha iyi bir altyapı üzerinde 300$350 \mathrm{~km} /$ saat'lik işletim hızları hedeflenmektedir. $\mathrm{Bu}$ da 1 ila 1,5 saatlik seyahat süreleri ile Ankara'dan İstanbul'a yolculuk anlamına gelmektedir. Konya-Karaman-Antalya-Mersin YHD hatt1 ve Eskişehir-Kütahya-Antalya YHD hattı planlanan diğer yatırımlardır. Diğer taraftan ise Sivas-Malatya-Diyarbakır YHD hattı ve Ankara-Nevşehir-Kayseri YHD hattı da planlanan hatlar arasındadır. Bir diğer bahsi geçen hat ise Ankara-Çankırı-Samsun YHD hattı olup bir diğeri ise Erzincan-Gümüşhane-Trabzon YHD hattıdir.

Edirne'ye ulaşacak YHD hattı Bulgaristan ve Yunanistan'a bağlanacak iken Kars'a ulaşacak hızlı demiryolu hattı ise Bakü-Tiflis-Ahıska YHD hattı ile birleşecektir. Bakü-Tiflis-Ahıska 
hattının tamamlanmasında ise ülkemizin önemli katkıları olmuştur. Hâlihazırda söz konusu hat da işletime alınmış olup Kars'tan yüklenen yük oldukça kısalan süreler ile Hazar Denizi'ne ve oradan da Kazakistan ve Asya ülkelerine ulaşmaktadır.

Ülkemizde konvansiyonel hatlar üzerine YHD bağlantısı bulunmamaktadır. Doğrudan yüksek hızlı demiryolu altyapı inşası ile süreç ilerlemektedir. Ancak ülkenin çeşitli bölgelerinde (güney ve kuzey) çeşitli hat bağlantılarının konvansiyonel demiryolu hatlarının iyileştirilmesi ile hızlı demiryolu hat işletimi olarak gerçekleştirilmesine yönelik çalışmalar bulunmaktadır. Şu ana kadar yük ve yolcu taşımacılığının birlikte ya da çift hat olarak gerçekleştiği bir YHD hat uygulaması da gerçekleştirilmemiştir.

\section{Sonuçlar ve Tartışma}

Yüksek hızlı demiryolu ağları Avrupa sathında sürekli bir ilerleme periyodundadır. Kitada ülkelerin demiryolu kültürü ve hizmet anlayış1, politik düşünceleri, kentsel oluşumları ve merkezden uzaklaşma süreçleri bu ilerlemenin şeklini belirlemekte ve çeşitlendirmektedir. Fransa ve İspanya'da bu noktada bir sistematik yakalandığı, ekolün elde edildiği söylenebilir. Söz konusu sistematikte başkent merkezliğini tahkim edici yapım ve işletme süreçleri ile birbirinden uzak aralıklarla daha az sayıda istasyonlardan söz edilebilir. İspanya ve Fransa'nın nihai amaçları ulaştırma ağlarının yegâne merkezlerine dönüşen iki başkenti birbirine bağlamaktır. Yüksek hızlı demiryolları için bunları kapsayan ama bunlardan da öte çeşitli tasniflerden söz edilebilir. Söz konusu tasnifler esas alınacak olur ise bir güzergâh sathında ara istasyon kentleri ana istasyonlardaki büyük kentlere olan mesafelerine göre ölçeklendirilip ele alınabilir. Yüksek hızlı demiryollarının gerçek anlamda bir analizi, zaman ölçekli konumsal bazlı ulusal, kentsel ve de bölgesel çapta geleneksel bağlamda gerçekleştirilmektedir. Mesela üretilen seyahat maliyeti potansiyel erişilebilirlik için bir ölçek olabilmektedir. Bununla birlikte bir erişilebilirlik tahmin ve hesap unsuru olarak yolculuk süresi, maliyet ve seyir frekansları anlamında kullanılabilir [12].

Yüksek hızlı demiryollarının dünya sathında hâlihazır (konvansiyonel) altyapılar üstünde 200 $\mathrm{km} / \mathrm{saat}$ hızlarda işletildikleri görülmektedir. Bunun üzerindeki hızlar birçok ülkede yakalanabilmektedir, daha fevkindeki hızlara da test fazında erişilebilmektedir. Fransa, Çin, İspanya ve Japonya gibi ülkelerde YHD işletmesinde $250 \mathrm{~km} / \mathrm{saat}$ ve üstü hızlar yakalanabilmektedir. Çin ve İspanya yüksek hızlı demiryolunda nispeten çok yeni olmalarına karşın önemli atılımlarla dünya liderliğindeki yerlerini almış iken Japonya ve Fransa ise 50 yıllık tecrübelerini teknik atılımları ile de tahkim edebilmişlerdir [12]. Yine uzun yıllardır yüksek hızlı demiryolu (YHD) sistematiğinde yer alan ülkelerden Almanya hem ulusal ve hem de bölgesel çapta büyük bir ağı gerçekleştirebilmiş olup bu ülke de dâhil olmak üzere İtalya ve Britanya belirli hız limitlerinden öteye henüz geçememişlerdir. Türkiye'de ise yapılan ilk yüksek hızlı demiryolu (YHD) hatlarının işletimleri $200-250 \mathrm{~km} /$ saat aralıklarındadır. $\mathrm{Bu}$ durum Ankara-Eskişehir-İstanbul, AnkaraKonya yüksek hızlı demiryolu (YHD) hatları için böyledir. Ülkemizin geneli itibari ile Avrupa'nın geneline nazaran daha engebeli arazi yapısı da hız alma ve hız kesme olanaklarını ister istemez kısıtlamaktadır. Buna göre kimi güzergâhlarda hat kilometresinin artmasi nedeni ile maliyet artışı ile karşılașılır iken kimi güzergâhlarda ise yatay kurb sayısındaki fazlalık nedeni ile hızlarda düşüş ile karşılaşılmaktadır. Dolayısı ile konu sadece yapılan altyapının sınıfi ile ilgili değildir. Buna Ankara-Konya YHD hattındaki durum örnek olarak verilebilir. Zira bu hat Türkiye geneline göre düzlük bir topografya üzerinde olmasından dolayı inşa süreci de daha kısa sürmüş olup, Ankara-Eskişehir-İstanbul YHD hattı ile aynı altyapı özelliklerine sahip olmasına karşın daha yüksek hızlarına ulaşılabilmiştir. Ve fakat ülkemizde yüksek hızlı demiryolu olarak adlandırılan hatların hem hız 
hem altyapı ve hem de diğer kıstasları itibari ile bugün için yüksek hızlı demiryolu sınıfında olduğu söylenebilir.

Ülkemizde hâlihazırda Ankara merkezli olarak bir YHD ağ yapısı ortaya çıkacaktır. Günümüz itibari ile önümüzdeki dönemde işletime alınmaya en yakın görünen yüksek hızlı demiryolu hatları ise Ankara-Yozgat-Sivas YHD hatt1, Ankara-Afyon-Manisa-İzmir YHD hatt1 ve Bilecik-Bursa(Yenişehir)-Balıkesir (Bandırma) YHD hattıdır. $\mathrm{Bu}$ hatlar tamamlandığında Türkiye'nin en büyük 4 ili birbirine yüksek hızlı demiryolu ile bağlanmış olacaktır.

\section{Teșekkür}

Akademik çalışmalarımızda emeği geçen hocalarımıza ve arkadaşlarımıza teşekkür ederiz.

\section{Kaynaklar}

[1] Taipador, F. J., Burckhart, K., Martí-Henneberg, J., 2009, "Characterizing European High Speed Train Stations Using İntermodal Time and Entropy Metrics", Transportation Research Part A: Policy and Practice, Cilt 43, Say1 2, ss. 197-208.

[2] AB Ulaştırma Politikaları-1, URL: http://www.ulastirmadunyasi.com/?p=8 (Erişim Tarihi: 12.08.2012)

[3] Ho, S. P., Liu, L. Y., 2002, “An Option Pricing-Based Model for Evaluating the Financial Viability of Privatized Infrastructure Projects", Construction Management \& Economics, Cilt 20, Say1 2, ss. 143156.

[4] Chen, C.,\&Hall, P. (2011). The impacts of high-speed trains on British economic geography: A study of the UK's Inter City 125/225 and its effects. Journal of Transport Geography, 19(4), 689-704. doi:10.1016/j.jtrangeo.2010.08.010

[5] Takatsu, T., 2007, "The History and Future of HighSpeed Railways in Japan”. Japan Railway \& Transport Review, Say1 48, ss. 6-21.

[6] Golobiĉ, M.,\&Marot, N. (2011). Territorial impact assessment: Integrating territorial aspects in sectoral policies. Evaluation and program planning, 34(3), 163-173. doi:10.1016/j. evalprogplan.2011.02.009

[7] AB Ulaştırma politikaları-4, URL: http://www.ulastirmadunyasi.com/?p=8 (Erişim Tarihi: 14.02.2011)

[8] Mancini, G., Malfatti, A., Violi, A. G., Matschke, G. "Effects of Experimental Bogie Fairings on The
Aerodynamic Drag of the ETR 500 High Speed Train". Proceedings of the World Congress of Railway Research WCRR, 2001.

[9] Arduin, J. P., Ni, J., 2005, "French TGV Network Development", Japan Railway \& Transport Review, Cilt 40, Say1 3, ss. 22-28.

[10] Crafts, N., 2009, “Transport Infrastructure Investment: Implications for Growth and Productivity", Oxford Review of Economic Policy, Cilt 25, Say1 3, ss. 327-343.

[11] Givoni, M., 2006, "Development and Impact of the Modern High-Speed Train: A Review", Transport reviews, Cilt 26, Sayı 5, ss. 593-611.

[12] Brezzi, M.,\&Veneri, P. (2015). Assessing polycentric urban systems in the OECD: Country, regional and metropolitan perspectives. European Planning Studies, 23(6), 1128-1145. doi:10. 1080/09654313.2014.905005. 